\title{
Teknologi Dalam Kontestasi Berdemokrasi
}

Bagus Surya, Habib Ma’rif, Heri Satriawan, Muhammad Adib Rafii

Universitas Indonesia

bagus.surya81@ui.ac.id

\begin{abstract}
Abstrak
Penulisan ini bertujuan untuk memaparkan Penggunaan Teknologi Dalam Kontestasi Berdemokrasi yang diteliti menggunakan metode campuran (kualitatif dan kuantitatif) dengan data sekunder untuk melihat pengaruh dari Kemajuan Teknologi dan Informasi. Terlebih lagi pengunaan teknologi dalam demokrasi, atau lebih dikenal dengan istilah e-democracy adalah subproduk dari e-governance yang dapat bantu mempercepat proses good governance dalam proses pemerintahan. Adapun keterlibatan masyarakat juga dalam e-governance juga yang diharapkan pemerintah untuk membantu transparansi seperti media massa untuk memaparkan data dan informasi yang bisa diakses dengan cepat dan mudah, Selain itu, penggunaan quick count dalam berdemokrasi juga dipakai untuk prediksi bisa mendorong politisi untuk lebih semangat dalam kontestasi politik, dan system e-voting yang memanfaatkan jaringan dalam pengolahan suara. Semua ini diharapkan untuk memajukan sistem kontestasi politik agar lebih cepat, efektif dan efisien, walaupun masih ada kelemahan dalam praktiknya.
\end{abstract}

Kata Kunci : Teknologi Informasi, Demokrasi, dan e-demokrasi

\begin{abstract}
This article was written with purpose of displaying what Information Technology able to do with certain nation's democratic process using mixed secondary data (qualitative and quantitative). The term e-democracy derives from e-governance which is using electronic in governance process to achieve good governance that doesn't only restricted from the government's perspective but also the societies. From the mass media to quick count surveyor, and the government's initiatives of taking online votes or widely known as e-votes. Although the purpose is to provide transparency and accountability effective and efficiently, there are still flaws regarding its practice.
\end{abstract}

Keywords : Information Technology, Democracy, and e-democracy

\section{PENDAHULUAN}

Di era perkembangan teknologi yang semakin canggih dan maju dengan keterbukaan informasi yang bisa diakses oleh setiap masyarakat, perkembangan demokrasi tidak akan lepas dari Teknologi dan Informasi di era 4.0. Dalam berdemokrasi setiap masyarakat dapat berkomentar tentang apa saja yang terkait dengan politik, ekonomi hukum dan lainlain. Dengan adanya kemajuan dalam bidang teknologi dan informasi ini masyarakat bisa mengawasi kinerja pemerintah dan juga bisa menanggapi serta memberikan solusi 
Dalam berdemokrasi, tentunya kerahasiaan, transaparansi, kejujuran, keadilan dan ketepatan informasi yang berkaitan dengan pemilu, pilpres dan pilkada itu sangatlah dibutuhkan, dengan adanya bantuan dari teknologi yang mendukung, tentunya informasi itu lebih mudah untuk diakses dalam bentuk elektronik, dengan memanfaatkan teknologi, kegiatan kampanye banyak muncul dari media massa seperti televisi maupun radio, tanpa meninggalkan media cetak sebagai teknologi pendahulu, tentunya dengan adanya perkembangan teknologi, khusunya pada teknologi informasi dan komunikasi, mampu membuat peningkatan partisipasi masyarakat dalam kegiatan demokrasi serta tidak kemajuan teknologi diharapkan tidak disalahgunakan seperti untuk kampanya negative yang saling hina dan bisa menjatuhkan lawan politik.

Kemajuan demokrasi di Indonesia dimulai dan ditandai pada era-98 hal tersebut dapat dilihat dari semakin banyaknya keterlibatan dari elemen masyarakat dalam berpolitik, demikian juga dengan diberikannya kebebasan pers berbicara (Setiadi, 2009). Dewasa ini dengan adanya kemajuan pada teknologi dan informasi, kegiatan demokrasi mulai terasa mudah, cepat, dan murah untuk diakses oleh siapa saja, sebagai seorang pengguna dari teknologi kita sangatlah dimungkinkan untuk memberikan masukan dan opini mengenai kebijakan ataupun isu-isu yang ada dalam masyarakat dan diatas (pemerintahan). Pada posisi sebagai seorang pengguna dari teknologi tidak menutup kemungkinan dalam dibuatnya system ataupun aplikasi yang digunakan dalam pencapaian tujuan politik.

Dengan memperhatikan aspek politik dan sensitifitas dari kegiatan demokrasi di Indonesia, maka digunakanlah teknologi-teknologi dalam menunjang demokrasi yang nantinya kita kenal dengan e-democracy seperti halnya dengan penggunaan quick count,e-voting dan penggunaan media massa baik itu dalam Pemlihan Umum dan Pilkada, dengan digunakannya teknologi dalam kontestasi berdemokrasi bisa memberikan kemudahan dan efisiensi biaya yang dikeluarkan, jadi di era kemajuan teknologi saat ini bisa menunjang demokrasi di Indonesia.

1. Teknologi Informasi

Teknologi Informasi merupakan teknologi yang digunakan dalam pengolahan data yang diubah menjadi sebuah informasi yang mudah dipahami dan dimengerti.

Menurut Bambang Warsita (2008:135) teknologi informasi itu adalah sarana dan prasarana (hardware, software, useware) system dan metode untuk memperoleh, megirimkan, mengolah, menafsirkan, menyimpan dan menggunakan data tersebut secara bermakna dan berguna. Teknologi informasi itu merupakan sebuah bentuk umum yang menjelasakan dan atau menggambarkan setiap teknologi yang membenatu dalam menghasilkan, memanipulasi, menyimpan, mengkomunikasikan dan atau untuk menyampaikan informasi tersebut.

Penggunaan teknologi didalam dunia Pemerintahan digunakan sebagai penghubung antara keperluan penduduk, bisnis dan kegiatan lainnya sebagai bagian dari tuntutan masyarakat, dalam penerapan $e$ government untuk meningkatkan kegiatan transparansi dalam membangun pemerintahan yang bersih dan terbuka terhadap masyarakatnya. Teknologi dalam kontestasi demokrasi juga digunakan untuk memudahkan dalam Pemilu, Pilkada dengan cara memanfaatkan teknologi seperti media massa, $e$ voting dan quick count.

2. Demokrasi

Pengertian demokrasi dapat dilihat dari dua istilah yakni dari segi epistemologis dan terminologis. Secara epistemologis, demokrasi terdiri dari dua kata yang berasal dari

Bahasa Yunani yakni “demos” yang berarti rakyat atau penduduk dan "cratos" yang berarti kekuasaan atau kedaulatan. Jadi secara Bahasa demos-cratos adalah keadaan negara dimana dalam system pemerintahannya kedaulatan itu berada ditangan rakyat, dengan kekuasaan tertinggi berada dalam keputusan Bersama rakyat, pemerintahan rakyat dan oleh rakyat. 
Dewasa ini dengan memanfaatkan teknologi yang semakin maju dan berkembang, demokrasi di era ini sudah mulai memanfaatkan kemajuan teknologi dengan dikenalnya e-democracy yang dirumuskan sebagai penggunaan TIK untuk memfasilitasi, memudahkan dan meningkatkan kinerja demokrasi, e-democracy sendiri dalam pemanfaatannya di Indonesia dengan digunakannya e-voting, quick count dan peran media massa.

E-governance

Bannister (2012) melihat bagaiman $e$ governance sebagai pengaplikasian dari teknologi informasi/ICT dalam segala bidang pemerintahan untuk mengatur, atau mengubah sepenuhnya segi struktur, dan proses pemerintahan yang sebelumnya tidak pernah terpenuhi tanpa adanya teknologi tersebut Untuk mengumpulkan seluruh informasi yang dibutuhkan pemilu, pemerintah membutuhkan satu sistem pangkalan data yang sudah menghimpun informasi secara keseluruhan. Maka itu pemerintah memanfaatkan big data dalam mengoperasikan sistem informasinya

Menurut Zhan (2017), big data digunakan sebagai aset informasi virtual yang dapat dianalisa, disimpan, bisa dibagikan, dan diproses oleh organisasi. Big data juga bisa disebut sebagai pangkalan data elektronik yang bersifat digital. Diantara cendekiawan, sulit untuk menjelaskan akurat bagaimana konsep big data secara teoritis. Namun, teori yang populer mengenai big data ini disebut sebagai Teori lima V yang menjelaskan sifat dan fungsi dari Big Data tersebut.

1. Volume: Ukuran data yang besar Variety: Ragam bentuk format data (pdf, jpg, docx, xlsx, dll)

2. Velocity: Kecepatan mengunggah dan mengunduh data

3. Value: Perubahan bentuk/format yang membuat input menjadi output sehingga menjadi suatu kebijakan baru (misalkan, layanan satu pintu/no wrong door policy).

4. Veracity: Keakuratan dalam memprosesi data (survei kualitas, kepuasan masyarakat, dll).
Peran Media Massa

Penggunaan media massa memiliki beberapa fungsi bagi masyarakat (McQuail, 2011). Pertama, Media massa sebagai pemberi informasi bagi masyarakat. Segala informasi tersebar bebas di media massa dan menjadi konsumsi publik. Kedua, adanya kolom komentar memberikan peluang terhadap masyarakat untuk bertanya dan lebih memahami informasi. Keberadaan kolom komentar juga memberikan kesempatan bagi masyarakat untuk kritis terhadap informasi yang diberikan. Ketiga, media massa juga menghubungkan masyarakat dalam memberi respon terhadap lingkungan. Keempat, fungsi media massa juga dapat menjadi sarana proses kesepakatan antar pihak. Dan Kelima, media massa dapat menjadi ekspresi masyarakat dan nilai-nilai budaya juga dapat tersalurkan pada media massa.

\section{METODE}

Pendekatan penelitian dalam makalah ini menggunakan pendekatan campuran. Pendekatan dengan menggabungkan data kualitatif dan kuantitatif dalam menganalisis data. Proses olah data dilakukan dengan cara mendeskripsikan fakta menjadi hasil analisis. Selain itu, menekankan pula pada aspek numerikal sebagai sumber datanya. Sehingga kesimpulan dan hasil akhir penelitian merupakan gabungan dari hasil olah data verbal dan numerikal.

pengumpulan data yang digunakan adalah pengumpulan data sekunder. Data diperoleh secara tidak langsung. Data dikumpulkan dari pihak ketiga dengan berbagai cara baik secara komersial maupun non komersial. Data dikumpulkan dari literatur-literatur di internet dan buku yang sesuai dengan penelitian. 


\section{HASIL}

Quick count di dunia muncul pada era tahun 1980-an pada negara-negara Eropa timur dan afrika lalu di Asia tenggara pertamakali dilakukan pada tahun 1986 saat pemili di negara Philipin sedangkan di Indonesia mengenal metode ini pada era tahun 1990an, dan Indonesia sebenarnya sudah melakukan metode ini pada pemilu tahun 1997 dan pemilu tahun 1999 tetapi tidak terlalu di publikasi kan kepada masyarakat sehingga tidak terlalu dikenal oleh masyarakat tetapi sekarang metode quick count ini menjadi hal yang sangat di nantinanti oleh masyarakat pada saat pemilu sedang berlansung. Quick Count dikenalkan untuk mengawali hasil pemungutan suara dalam pemilu dimana Quick Count ini adalah sebuah metode dalam statistik yang bertujuan untuk mengetahui hasil dari sebuah pemilihan suara dengan cara mengambil sampel dari sejumlah tempat pemungutan suara atau TPS yang dimana Quick Count ini digunakan untuk mengetahui lebih cepat hasil dari sebuah pemilu yang dimana akan terlihat seberapa persen angka kemenangan dari salah satu calon dengan calon yang kalah sehingga pada saat penghitungan kertas suara bisa membuat tingkat kecurangan pemungutan hasil pemilu yang dilakukan secara lansung tidak dapat di curangi, karena apabila hasil penghitungan kertas yang dilakukan secara lansung berbeda jauh dengan Quick Count bisa di sinyalir terjadi sebuah kecurangan walaupun tidak juga di pastikan terjadi sebuah kecuranagan (Uyun, 2019).

Dan di Indonesia saat ini juga telah sangat menjamurnya sebuah lembaga-lembaga survey yang dimana pemerintah harus melakukan regulasi untuk mengatur hasil dari quick count yang dikeluarkan lembagalembaga survey dimana pemerintah telah mengeluarkan 6 peraturan yaitu

1. UU No.16 Tahun 1997 tentang Statistik

2. SK KPU no. 701 tahun 2003 pasal 14 ayat 1

3. Keputusan KPU no. 48 tahun 2004

4. Pasal 10 dalam Peraturan KPU no. 40 tahun 2008

5. Pasal 245 ayat 3 UU Pemilu, UU No 10 tahun 2008

6. Ketentuan Pidana

Dan dengan adanya quick count adalah satu bentuk dari sebuah negara yang demokrasi dimana menuntut partisipasi aktif dari masyarakat untuk memantau jalannya perhitungan suara pemilu dan juga quick count tidak juga bisa membuat masyarakat mendapatkan pemimpin yang baik karena quick count hanya sebatas penghitungan dari hasil suara, dan memndapatka seorang pemimpin yang berkualitas karena kita memilih seorang pemimpin lewat hitunghitungan suara yang di pilih oleh masyarakat, dan quick count tidak menjamin kesejahteraan publik tetapi dengan adanya quick count di dalam pemilihan umum di harapkan berjalan dengan jujur dan adil (Kurniawan, 2019). Dari quick count ini memberikan manfaat yang baik dan membuat metode quick count ini menjadi penting dalam beberapa hal pada saat pemilu seperti:

1. Mencegah terjadinya kecuranag dalam pemilihan umum, karena dengan pengumuman hasil-hasil survey yang dikeluarkan oleh lembaga-lembaga membuat para aparat atau para calon akan berfikir ulang jika melakukan kecuranagn dengan membandingkann hasil dari quick count dengan hasil resmi yang di keluarkan oleh KPU

2. Dengan adanya quick count masyarakat bahkan calon bisa memprediksi hasil dari pemilu sebelum keputusan akhir yang di keluarkan oleh KPU

3. Quick count meningkatkan kepercayaan kepada proses pemiliham umum dan hasil akhir melalui laporan kualitas proses pemilu dengan data kualitatif yang diperoleh dari quick count

4. Quick count mendorong partisipasi aktif masyarakat untuk peduli dan menjadi pemantauan hasil akhir pemilu dan telah menjadi budaya baru dengan memantau setiap perkembanagan angka yang dikeluarkan lembaga-lembaga survey quick count

Tetapi dengan banyak nya kemanfaatan yang didapatkan dari metode Quick count ini masih memiliki kekuranagn seperti margin error dari survey yang dilakukan lembagalembaga survey sehingga dari hasil yang di kelurakan oleh quick count tidak lah akurat hanya sebatas melihat 
hasil sementara yang tidak bisa di jadikan hasil final dan juga pada saat lembaga-lembaga survey mengeluarkan hasil quick count membuat nilai tukar rupiah terhadap dolar AS lansung melesat
Data di atas memperlihatkan rata-rata dan standar deviasi dari variabel harga kurs USD rata-rata Harga kurs USD sebelum Pemilihan Presiden sebesar 11.837 dengan standar deviasi sebesar 101,347 dan Rata-rata Harga kurs USD sesudah Pemilihan Presiden sebesar 11.722 dengan standar deviasi sebesar 97,297 (Silalahi, 2017).

Tabel 1 Harga Kurs USD

\begin{tabular}{|l|l|l|l|}
\hline Variabel & Kondisi & Mean & $\begin{array}{l}\text { Standar } \\
\text { deviasi }\end{array}$ \\
\hline $\begin{array}{l}\text { Harga } \\
\text { Kurs } \\
\text { USD }\end{array}$ & Sebelum & 11.837 & 101,347 \\
Sesudah & 11.722 & 97,297 \\
\hline
\end{tabular}

\section{Penggunaan $e$-vote dalam Memberikan Kemudahan Berdemokrasi}

Penerapan sistem $e$-voting bisa dilihat dari perkembangan e-governmentnya (Moynihan, 2004). Sistem yang menerapkan metode pemilihan umum melalui jaringan elektronik sebagai pencapaian dari teknologi informasi yang berpotensi menciptakan pemilu yang efektif dan efisien.

Dengan mengetahui keberadaan dan kebermanfaatan dari big data dalam sistem informasi, maka komisi pemilihan bisa memberlakukan sistem pemilihan metode $e$ voting sendiri juga terbagi menjadi 2 menurut Riera \& Brown (2003):

1. E-Voting: Kotak suara yang sudah dilengkapi dengan teknologi direct recording electronic. Sistem ini sudah terhubung dengan big data nama-nama calon daftar pemilih tetap yang memiliki hak suara. Tentu pemilih wajib datang ke tempat yang sudah terverifikasi sebagai kotak suara sah. Namun, data pilihan langsung terkirim dan dikelola oleh server pusat

2. I-Voting: Pemilih menetapkan suaranya lewat medium diluar tempat yang ditentukan, namun memanfaatkan internet, nirkabel atau tidak dengan catatan bahwa aplikasi ini disetujui oleh otoritas pemilihan umum.
Melihat dinamika dari sistem e-voting didunia, pertamakali sistem $i$-voting dilaksanakan di Florida, Amerika Serikat pada tahun 2000 (Habibi \& Nurmandi, 2018). Tetapi, terjadi kendala saat pengadaan pemilu yang justru menjadi kegagalan. Menurut Riera \& Brown, hal yang menyebabkan ini terjadi diantaranya: Peralatan yang rusak, surat suara yang membingungkan, pendaftaran yang tidak teratur, kesalahan dalam operasi tempat pemungutan suara dan masalah hilangnya 4 hingga 6 juta suara

Jejak buruk ini diperbaiki, namun pada Pemilu Estonia yang membuktikan bahwa sistem e-voting bisa diterapkan dan dapat dipercaya. Hal ini bisa dilihat dari azas keterbukaan bagi warga Estonia dimana pada tahun 2000, Estonia menjadi satu-satunya negara uni-eropa yang memberikan internet sebagai hak sipil (Trechsel \& Vassil, 2010). Walaupun terkesan salah satu negara miskin Uni Eropa, pada tahun 2005 pertama kali Estonia menerapkan sistem $i$-voting. Pada tahun pertama diselenggarakan, $i$-vote hanya digunakan untuk pemilihan DPRD. Dari 1.059.292 pemilih, terdapat 9.317 pengguna $i$-voters dengan persentase 1.9\% (Detikcom, 2007).

Pada tahun 2007, i-voters sudah bisa digunakan juga untuk penggunaan general election/pemilihan umum yang dimana sudah tersedia untuk memilih anggota parlemen umum/DPR. Jumlah daftar pemilih tetap pada saat itu sebanyak 940.000 penduduk. 30.275 atau 
$3.4 \%$ diantaranya pengguna $i$-vote. Statistik yang terakhir menunjukkan pada tahun 2019 , dari 887.420 pemilih tetap, 247.232 atau $43.8 \%$ berasal dari $i$-vote (Valimised, 2019). Namun, apa saja faktor agar penduduk menggunakan sistem ini? Ülle \& Martens (2006) menyebutkan ada faktor-faktor yang menyebabkan sistem pemilihan menjadi lebih mudah.

Pertama, sifat untuk memilih lewat internet bersifat opsional, pemilih masih bisa untuk datang ke DPT dan menggunakan kotak suara/ballot biasa. Kedua, sikap warga Estonia terhadap pemilu tidak berubah, malah justru membantu mereka yang secara fisik tidak bisa datang seperti kehalangan untuk berhadir karena sakit atau diluar DPT.

Tetapi, kelemahan yang disampaikan oleh Ülle \& Martens berpangkal dari legalitas dan legitimasi data, kemudian komitmen akan kejujuran $e$-voting yang masih menjadi perdebatan yang dibuktikan oleh Moynihan (2004) sebab ketidaksiapan jika terjadi kerusakan teknologi yang bisa saja membatalkan keputusan apabila datanya hilang, terlebih lagi Wolchok dkk ( 2010) mengatakan adanya keraguan tentang kredibilitas kerahasiaan pilihan.

Namun, bagaimana sikap KPU dalam menanggapi tantangan penggunaan $e$-vote? Nyatanya, KPU sudah menggunakan rekapitulasi elektronik/e-rekap yang dikenal sebagai Sistem Informasi Perhitungan Suara/SITUNG. Walaupun voting masih menggunakan kotak suara konvensional, pengelolaannya dilakukan secara online.

Tetapi, Ketua KPU Arief Budiman (dalam Wardani, 2017) menjelaskan ada beberapa faktor yang menahan KPU untuk menerapkan e-vote. Pertama, belum semua TPS memiliki listrik yang cukup, jika sanggup maka 810.000 TPS akan terhubung, dan pemerintah perlu menyediakan 3 komputer untuk setiap TPS yang berjumlah 2.430.000 terhitung. Kedua, KPU tidak mau mengambil resiko untuk menunda proses pemilihan kendala teknis karena resiko penggunaan infrastruktur yang minimal. Ketiga, beberapa kantor KPU dibeberapa Kabupaten/Kota masih bersifat mengontrak. Percuma juga, sebab kalau sudah menetap, pun gudang belum mencukupi untuk menyimpan alat infrastruktur
Menkominfo optimis untuk menerapkan e-vote sekiranya 2029 (Katadata, 2019). Malah, rencananya ini lebih terfokus pada bentuk i-vote dengan melibatkan Badan Pengkajian dan Penerapan Teknologi/BPPT. Hal ini bisa terjadi apabila data identitas pengguna ponsel/authenticator, dalam konteks ini yaitu Nomor Induk Kependudukan sudah terhubung dengan Subscriber Digital Number atau nomor ponsel. Syaratnya, NIK yang teregistrasi di nomor ponsel mesto sungguhan dan tidak fiktif.

KPU dan Menkominfo sama-sama setuju mengenai percobaan yang harus dilakukan pada Pilkada terlebih dahulu. Saat ini, masih ada 9 bulan sebelum pelaksanaan Pilkada. KPU perlu melakukan penguatan infrastruktur bersama BPPT, Badan Sandi Negara/BSSN, dan Pemda terutama Pemkot/kab sebagai prasarana pendidik yang bersedia untuk menyiapkan SDM pemilih tetap agar mampu menggunakan internet.

Akhir kata, walaupun ada kebaikan dan keburukan dari sebuah fitur, tetap saja $e$-vote ini berpotensi untuk meningkatkan partisipasi masyarakat dalam bidang teknologi yang saat ini sudah mengikat sistem dunia dengan apa yang kita ketahui sebagai Industri 4.0.

\section{Peran Media Massa dalam e-democracy}

Perkembangan teknologi saat ini begitu masif sehingga mempengaruhi kehidupan masyarakat Indonesia. Salah satu teknologi yang paling berkembang saat ini adalah teknologi informasi. Dewasa ini, akses informasi sangat mudah dan cepat. Media massa saat ini menjamur di Indonesia dan memiliki dampak yang signifikan terhadap penyebaran informasi. Indonesia yang menganut paham demokrasi tentu nya terpengaruh dengan banyaknya media massa. Media massa tidak hanya menjadi sarana informasi, tetapi juga dapat menjadi kekuatan politik yang sangat kuat. 
Dalam kontestasi berdemokrasi, media massa menjadi sarana informasi dalam penyelenggaraan pemilu (Gunawan, 2018). Kondisi politik yang terjadi saat pemilu merupakan hasil ciptaan media massa. Media massa dituntut untuk netral dan profesional. Media massa kemudian menjadi penting karena menyediakan suatu wadah komunikasi yang tidak ada distorsi bagi masyarakat (Gunawan, 2018). Media massa menjadi tempat dimana individu-individu bisa berinteraksi satu sama lain tanpa batasan wilayah dan waktu.

Media massa dapat pula menjadi ruang publik atau yang sering disebut public sphere. Public sphere dapat diartikan sebagai ruang tempat terjadinya debat publik dan berbagai diskusi publik tentang masalah publik yang setiap individu memiliki kesempatan menyampaikan aspirasinya. Menurut Harbernas, public sphere dapat menjadi arena independensi antara publik dan pemerintah, sehingga aksesnya terbuka dan dapat diperiksa oleh negara (Tissu, 2000).

Media massa juga dapat digunakan sebagai media untuk berdiskusi terkait politik, sosial, ekonomi, dan budaya yang sedang terjadi di Indonesia. Masyarakat dapat secara bebas menyalurkan aspirasinya dan memberikan komentar terkait kondisi yang terjadi. Penggunaan media massa dalam kontestasi berdemokrasi tentunya memiliki dampak positif dan negatif. Sebagai negara berkembang, Indonesia tentunya mendapat konsekuensi dari perkembangan media massa.Informasi yang sangat bebas tersebar di media massa membawa dampak yang negatif pula bagi masyarakat. Data yang terkirim di media massa sangat banyak dan menimbulkan berita-berita yang hoax dan tidak dapat dipertanggungjawabkan kebenarannya. Dimasa pemilu sedang berlangsung, media massa dapat memicu ketegangan antar pendukung partai politik. Adanya serangan secara verbal juga menimbulkan kekacauan di media massa.

Melihat sejarah media massa di Indonesia, dalam masa Orde Baru media massa diberikan batasan dalam menyebarkan informasi (Gunawan, 2018). Rezim pemerintahan Soeharto melakukan kontrol terhadap penyebaran informasi agar informasi yang disebarkan tidak menjelekkan pemerintah. Sehingga informasi dan pendapat yang tersebar di media massa penuh akan kepentingan politik kelompok tertentu. Pada masa reformasi, salah satu tuntutan masyarakat adalah adanya kebebasan pers, dimana media massa dapat dengan bebas mengekspresikan dan mengirimkan informasi kepada khalayak luas tanpa intevensi pemerintah atau pihak manapun. Sehingga media massa dapat kembali menyebarkan informasi yang netral dan faktual sehingga memberikan manfaat bagi masyarakat.

Media massa menjadi sarana yang efektif dalam membangun minat dan kesadaran masyarakat akan kontestasi berdemokrasi. Dalam Pemilihan Presiden 2019 (Pilpres 2019) dapat dilihat bahwa media massa menjadi sarana masyarakat dalam memberikan pendapatnya mengenai pasangan calon presiden dan wakil presiden. Terbentuk pula polarisasi politik dan membentuk istilah cebong bagi pendukung 01 dan kampret bagi pendukung 02. Media massa menjadi arena pertarungan antar pendukung 01 dan 02 . Terdapat pula debat publik dari berbagai kalangan baik ilmuan dan politisi dalam satu mekanisme media massa.

Saat ini, tantangan terbesar media dalam kontestasi berdemokrasi adalah tingkat keakuratan berita dan perlindungan data pribadi. Seringkali kita jumpai di media massa terdapat berita-berita hoax yang menyebabkan timbulnya kekacauan. Berita tersebut berupa ujaran kebencian, pernyataan fitnah, dan kalimat provokatif yang bisa menyebabkan hancurnya persatuan (Alief, 2016). Selain itu, komentar atau postingan yang dilontarkan ke media massa dapat disalahgunakan. Apabila perkataan kita menyinggung seseorang, kita bisa dipidanakan oleh

UU ITE. Adanya UU ITE menjadi sarana pengawasan kegiatan media massa yang begitu masif tersebut.

Dalam menyikapi peran media massa dalam kontestasi berdemokrasi saat ini, kita perlu menggunakannya dengan bijak. Media massa dapat menjadi sumber informasi dan wadah aspirasi kita dalam mengutarakan pendapat. Namun, jangan sampai kita termakan hasutan dari media massa dan berita hoax yang beredar didalamnya. Semoga kedepannya media massa dapat menjadi sumber informasi yang berkualitas bagi masyarakat. Secara tidak langsung hal tersebut juga akan meningkatkan atmosfer kontestasi berdemokrasi yang lebih sehat lagi. 


\section{SIMPULAN}

Hasil analisis yang dilakukan penulis menunjukkan bahwa peran teknologi dalam hal ini quick count, e-vote, dan media massa memberikan pengaruh yang sangat signifikan dalam kontestasi berdemokrasi. Quick count dapat mendorong partisipasi masyarakat untuk peduli dan menjadi pemantau hasil akhir pemilu. Peran quick count juga dapat mencegah terjadinya kecurangan dalam pemilu. Disamping itu, quick count tidak dapat dijadikan keputusan akhir dalam pemilu. Penggunakan $e$-vote dalam hal ini $e$-voting dan $i$-voting mempermudah masyarakat dalam berpartisipasi di pemilu. Namun, e-vote memiliki kendala dalam masalah keamanan data yang mudah hilang dan dapat dimanipulasi. Peran penting media massa sangat vital dalam kontestasi berdemokrasi. Media massa menjadi sumber informasi dan wadah masyarakat dalam ber opini. Namun, memiliki dampak negatif terkait berita yang simpangsiur dan provokat

\section{DAFTAR PUSTAKA}

1. Alief, B. (2016, Desember). MUI: Berita Hoax Bisa Mengancam Persatuan dan Kesatuan Bangsa. Retrieved from detikNews: https://news.detik.com/berita/d3384849/mui-berita-hoax-bisamengancam-persatuan-dankesatuan-bangsa

2. Alwajih, A. (2014). Dilema EDemocracy di Indonesia:. Jurnal komunikasi, ISSN 1907-898X Volume 8, Nomor 2, April 2014, 139-154.

3. Amalia, D. (2017, Juli 10). Teknologi Dalam Kontestasi Berdemokrasi. Retrieved from geotines, diakses pada tanggal 28 November 2019 Pukul 11.39 AM: https://geotimes.co.id/opini/tek nologi-dalam-kontestasiberdemokrasi/

4. Bannister, F. (2012). Defining eGovernance. e-Service Journal, 3-25. 
5. Dwi, S. T., Wahyuningsih, D., \& dan Baegaqi, A. (2012). Demokrasi. Yogyakarta: Universitas Ahmad Dahlan.

6. Detikcom. (2007). Estonia Gelar Pemilu Online Pertama di Dunia. Diambil kembali dari inet.detik: https://inet.detik.com/cyberlife/d749814/estonia-gelar-pemiluonline-pertama-di-dunia

7. Gunawan, R. (2018). Fungsi Media Massa dalam Perspektif Negara Demokrasi terkait Penyelenggaraan Pemilu. Fakultas Hukum Unnes, 4(3), 1101-1118. Retrieved from https://journal.unnes.ac.id/sju/index.php/ snh

8. Habibi, M., \& Nurmandi, A. (2018). Dinamika Implementasi E-Voting di Berbagai Negara. Diambil kembali dari zenodo.org: http://doi.org/10.5281/zenodo.1295 466

9. Khoirul, S., \& Munif, A. (2015). Membangun Karakter Budaya Politik Dalam Berdemokrasi. ADDIN, Vol.9, No.2, Agustus 2015, 309-332.

10. Kurniawan, R. C. (2019). QUICK COUNT (Metode Hitung Cepat) DALAM PERSPEKTIF PEMILUKADA. Staf Pengajar FISIP Universitas Lampung, 3-11.

11. McQuail, D. (2011). Teori Komunikasi Massa. Jakarta: Salemba Humanika.

12. Moynihan, D. P. (2004). Building Secure Elections: E-Voting, Security, and Systems Theory.

Public Administration Review, Vol. 64, No. 5, 515-528.

13. Riera, A., \& Brown, P. (2003). Bringing Confidene to Electronic Voting. Electronic Journal of EGovernment, Vol. 1 no. 1, 43-50.
14. Sasmita, S. (2001). Demokrasi Dalam Bidang Digital. Demokrasi Vol. X No.2 Tahu 2001, 159-166.

15. Silalahi, S. P. (2017). Dampak Quick Qount Pilpres 2014 Terhadap Harga Kurs USD, Abnormal Return dan Aktivitas Volume Perdagangan Saham Di BEI (Uji Kasus Pada Saham yang Terdaftar Dalam Kelompok Perusahaan LQ-45) . Jurnal Ilmiah Methonomi, 137-138.

16. Tissu, D. K. (2000). International Communication Contiunuity and Change. New York Oxford University Press in.

17. Trechsel, A. H., \& Vassil, K. (2010). Internet Voting in Estonia (20052009). Florence: Robert Schuman Centre for Advance Studies, European University Institute.

18. Uyun, Y. H. (2019, April 19). ejarah Quick Count Pertama di Indonesia: Awal Pemilu 2004, Sempat Diancam dan Hasil Memuaskan. Retrieved from tribunnews.com: https://bogor.tribunnews.com/2019/0 4/19/sejarah-quick-count-pertama-diindonesia-awal-pemilu-2004-sempatdiancam-dan-hasil-memuaskan

19. Ülle, M., \& Martens, T. (2006). Evoting in Estonia 2005. The First Practice of Country-Wide Binding Internet Voting in the World. Electronic Voting 2006: 2nd International Workshop, CoOrganized by Council of Europe, ESF TED, IFIP WG 8.6 and E-Voting.CC, (hal. 15-26). Talinn, Estonia.

20. Valimised. (2019, Maret 8). Riigikogu Election 2019. Diambil kembali dari valimised.ee: https://rk2019.valimised.ee/en/votingresult/voting-result-main.html

21. Warsita, B. (2008). Teknologi Pembelajaran: Landasan \&Aplikasinya. Jakarta: Rineka. 
22. Winarno, B. (2008). Sistem Politik Indonesia Era Reformasi. Yogyakarta: Media Pressindo.

23. Wolchok, S., Wustrow, E., \& Halderman, J. A. (2010). Security Analysis of India's Electronic Voting Machines. Human Factors, 1-14.

24. Zhan, M. (2017). Big Data in the Public Sector: A Systematic Literature Review. Scandinavian Journal.
25. Wardani, H. L. (2017, 2 Mei). KPU: E-Voting Belum Bisa Dilakukan Saat Ini. mengutip dari: detikNews https://m.detik.com/news/berita/d3489522/kpu-e-voting-tidak-bisadilakukan-di-indonesia-saat-ini

26. Katadata. (2019, 9 Mei) Rudiantara Optimis E-Voting Bisa Berjalan Pada Tahun 2029. dikutip dari Katadata.com https://katadata.co.id/berita/2019/05/09/ rudiantara-optimistis-sistem-e-votingpemilu-bisa-berjalan-pada-2029 